\title{
Quantitative Fluorescent PCR (QF-PCR) on microsatellites, a fast and quantitative method to assay chimeric DNA samples in honeybees (Apis mellifera)*
}

\author{
Monica BERGEM ${ }^{\mathrm{a}}$, Arne RoseTH ${ }^{\mathrm{b}}$, Sigbjørn LIEN $^{\mathrm{a}, \mathrm{b}}$, Randi AAMODT ${ }^{\mathrm{a}}$ \\ ${ }^{a}$ Department of Animal and Aquacultural Sciences, Norwegian University of Life Sciences, 1432 Aas, Norway \\ ${ }^{\mathrm{b}}$ Center for Integrative Genetics (CIGENE), Norwegian University of Life Sciences, 1432 Aas, Norway
}

Received 15 July 2005 - Revised 8 December 2005 - Accepted 22 December 2005

\begin{abstract}
The production of chimeras by nuclear transfer or cell transplantation requires functional tools for the detection of individuals that have successfully incorporated donor material. Quantitative Fluorescent PCR (QF-PCR) on microsatellites was employed on artificial chimeric honeybee DNA samples, to develop protocols for detection and quantification of donor genotypes after nuclear transfer and cell transplantations into honeybee embryos. Standard curves were produced for three microsatellite markers and demonstrate that there is a close to linear correlation between the amounts of donor genotypes estimated with QFPCR and actual amounst of genotypes. The method was sensitive down to a $1 \%$ level and could detect and quantify small amounts of donor DNA in artificially mixed samples. QF-PCR offers fast and sensitive detection and quantification of genotypes and, thus, provides a useful tool for studies of chimeric honeybees and other species.
\end{abstract}

Quantitative Fluorescent PCR (QF-PCR) / microsatellites / nuclear transfer / honeybee / Apis mellifera

\section{INTRODUCTION}

Microsatellites are di, tri- or tetranucleotide repeats that are found randomly distributed throughout the genome. Quantitative analysis of microsatellite markers was first reported in 1993 (Cawkwell et al., 1993; Mansfield, 1993), as a tool in the diagnosis of tumourrelated allele-loss and Downs syndrome. Later, this method, Quantitative Fluorescent PCR (QF-PCR), was successfully used to detect other chromosomal diseases (Adinolfi et al., $1995,1997)$ and to analyse patients after bone marrow transplantations (Oberkirkher et al., 1995). The assay offers a specific, sensitive and quantitative analysis of microsatellites.

Corresponding author: M. Bergem, monica.bergem@umb.no

* Manuscript editor: Klaus Hartfelder
In the honeybee (Apis mellifera L.), several hundred microsatellites have been identified (Solignac et al., 2003), which provides new opportunities for bee research based on genotypic data not formerly available (Moritz et al., 2003).

Chimeras are individuals composed of cells from different parental lineages produced by nuclear transfer or cell transplantation. They have shown to be instrumental for understanding important issues in developmental biology (reviewed by West, 1999). The techniques for making and studying chimeras have been established for a large number of organisms, including the fruit fly (Illmensee, 1968), mouse (Tarowski, 1961) and zebrafish (Lin et al., 1992). Additionally, our lab has reported the production of honeybee chimeras by use of nuclear transfer (Omholt et al., 1995) and cell transplantation (Bergem et al., 2006). 
To date, microsatellites have been utilised to quantify levels of chimerism only in mice (Delhaise et al., 1993). The main objective of the present study was to develop protocols to detect and quantify chimeric honeybees after nuclear transfer and cell transplantation. Here we report the use of a QF-PCR protocol to quantify chimerism based on fluorescentlabelled primers, microcapillary electrophoresis and automated quantification.

\section{METHODS}

\subsection{Standard curves}

To demonstrate the use of QF-PCR, three standard curves were produced with different donorrecipient allele-designs to create an artificial nuclear transfer or cell transplantation experiment: (1) a standard curve to simulate chimeras with four alleles for a particular microsatellite marker, produced by a heterozygous donor and a heterozygous recipient with unequal alleles for the chosen marker (see Sect. 2.2), (2) a standard curve to simulate chimeras with two alleles for a particular microsatellite, produced by a donor and recipient, both homozygous and with unequal alleles for the chosen marker and (3) a standard curve to simulate chimeras with three alleles for a particular microsatellite, produced by a heterozygous donor and recipient, with two unequal alleles and one shared allele for the chosen marker.

Based on DNA extracts $(20 \mathrm{ng} / \mu \mathrm{L})$ from the genotyped and pre-selected donor and recipient, an array of $20 \mu \mathrm{L}$ samples was prepared with percentage ratios (recipient/donor) varying from 100/0 to $0 / 100$. Five replicates were used for each ratio between $100 / 0$ to $91 / 9,9 / 91$ to $0 / 100$ and three replicates were used for the remaining distributions. The assay included positive and negative controls. To demonstrate the production of chimeras we demanded at least $1 \%$ of donor genotype in total extracted DNA. The contribution of the donor was estimated as the sum of the peak heights of the donor alleles divided by the sum of the peak heights of all alleles. This estimated contribution was adjusted for the discrimination of short alleles by calculating the regression of true contribution of donor on estimated contribution of donor, and multiplying the estimated donor contributions by this regression factor to obtain the adjusted estimated donor contributions.

\subsection{DNA extraction, PCR and genotyping}

To select individuals for the experiments, randomly chosen honeybee larvae (Apis mellifera carnica) from several honeybee hives were collected. DNA was extracted by use of the DNeasy Tissue Kit (Qiagen). The absolute amount of DNA isolated from single larvae varied from $20-40 \mu \mathrm{g}$, dependent on the size of the larvae. The extracts were diluted to give final concentrations of $20 \mathrm{ng} / \mu \mathrm{L}$.

Microsatellites were amplified by use of polymerase chain reaction (PCR). The forward primers were labelled with fluorescent dye (NED and 6FAM) to facilitate the detection of fluorescently labelled PCR products during the microcapillary electrophoresis.

Target DNA sequences were amplified by PCR in $10 \mu \mathrm{L}$ of $1 \times$ Taq Gold PCR buffer containing 0.5 units of Taq Gold Polymerase (Applied Biosystems), $2.5 \mathrm{mM} \mathrm{MgCl}, 0.25 \mathrm{mM}$ dNTP, $2.5 \mathrm{pmol}$ of each primer and $\sim 100 \mathrm{ng}$ of genomic DNA. PCR reactions were run in a thermal cycler (GenAmp PCR System 2700/9700, Applied Biosystems) by the following criteria: hold at $95^{\circ} \mathrm{C}$ for $10 \mathrm{~min}, 30$ cycles with $30 \mathrm{~s}$ at $95^{\circ} \mathrm{C}, 30 \mathrm{~s}$ at $55^{\circ} \mathrm{C}, 1 \mathrm{~min}$ at $73{ }^{\circ} \mathrm{C}$ and a final hold at $73{ }^{\circ} \mathrm{C}$ for $25 \mathrm{~min}$.

PCR products were run on a 3730 Sequencer (DNA Analyzer, Applied Biosystems) and the electrophoresis gel data was analysed by GeneMapper v3.0 (Applied Biosystems). Quantification of microsatellites was based on emitted fluorescence at each allele position reflecting the number of amplified target sequences.

The GeneMapper electrophoretograms displayed information about allele length, peak height and peak area. In microsatellite analysis, the alleles of an individual for a certain marker appear as either one (homozygotes) or two (heterozygotes). Chimeric individuals have one to four alleles and thus produce one to four peaks.

Peak heights are correlated to the quantity of amplified PCR product and used here as an indication of the distribution of genotypes in a sample.

Markers ED1 (Accession No. U73922, Rowe et al., 1997), A8 (Accession No. AJ509237, Solignac et al., 2003) and A88 (Accession No. AJ509283, Solignac et al., 2003) were chosen, based on polymorphism, the amount of stutter bands produced and quality of displayed peaks in the electrophoretograms. Genotyped individuals were selected as donors and recipients based on allele combinations for the three markers. 


\section{RESULTS}

Standard curves were made to analyse individuals quantitatively after nuclear transfers and cell transplantations. As shown in Figure 1 , the method enabled a detection of genotypes with sensitivity of $1 \%$.

During PCR, shorter alleles in a sample were generally amplified to a larger extent than longer alleles (Figs. 2, 3). We found that peak heights were inversely correlated to allele length, but there was no general correlation among the markers in distance (in base pairs) between alleles and peak heights. Consequentially, the three standard curves produced were adjusted to compensate for possible artefacts. Corrected values were calculated by standard linear regression. For marker ED1 and A8, the correction was almost insignificant (factors 0.9887 and 0.9798 , respectively), however, for marker A88 (factor 1.4812) the adjustment produced a large improvement towards a one to one relationship between actual and estimated amount (Fig. 4). The standard curves demonstrated that there is an approximately linear correlation between the estimated ratios by QF-PCR and the actual ratios of added donor genotype.

\section{DISCUSSION}

We have developed a rapid technique with the potential for detection and quantification of genotypes in honeybee chimeras. However, QF-PCR can, in principle, be used to analyse chimeric individuals of any species where microsatellite markers are available. The method is fast, sensitive and less labourintensive than other available techniques, such as Real-Time PCR, which require comprehensive, time-consuming template preparation.

The study of chimeras has already provided in-depth knowledge about animal development and genetics (West, 1999), and is constantly reaching new areas and applications. Traditionally, chimeric individuals have been detected and studied by use of coat colour or biochemical markers, however, in recent years DNA-based methods such as Fluorescence. In situ Hybridization (FISH) (Martens
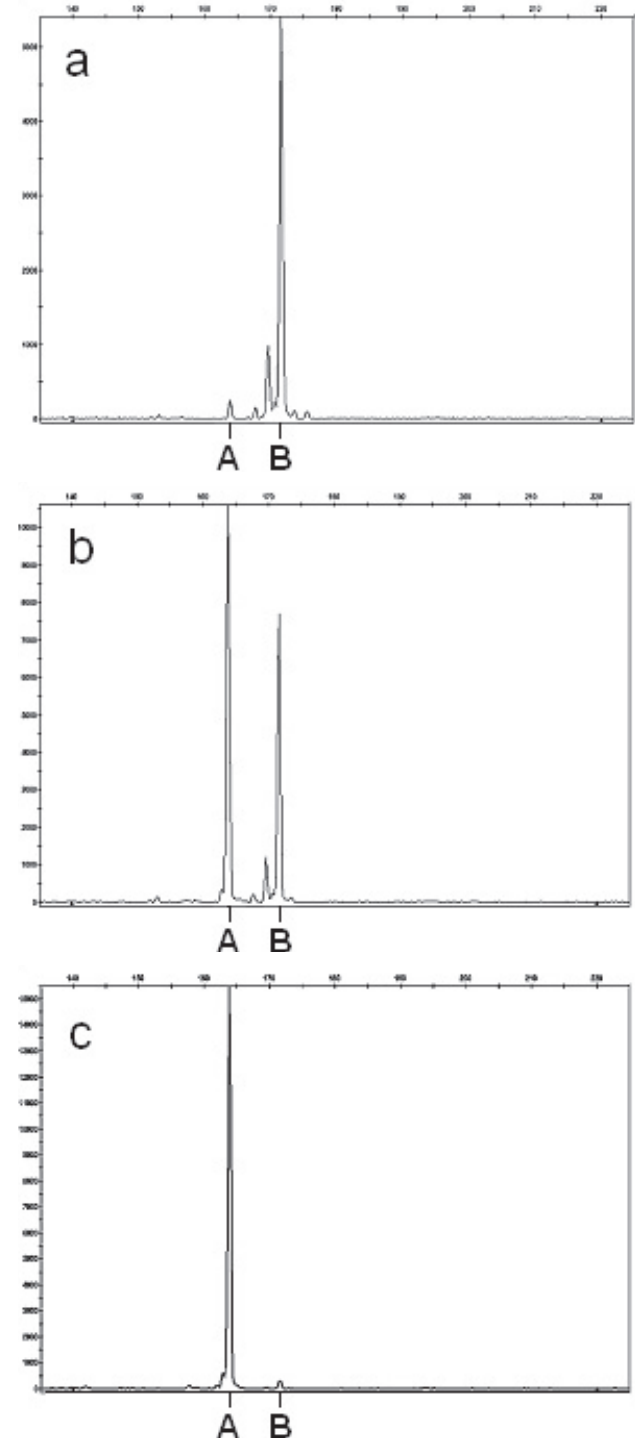

Figure 1. Example of quantification of genotypes by QF-PCR in artificial chimeras. Two homozygous individuals were mixed to simulate chimeras and analysed by marker A8. Donor genotype (allele A of 164 base pairs) and recipient genotype, (allele B of 172 base pairs) were represented in the electrophoretograms by peak heights and peak areas that were closely correlated to the actual ratios of the sample: recipient: donor 99:1 (a), 50:50 (b) and 1:99 (c). The $\mathrm{x}$-axis displays the computed length of PCR products in base pairs, as determined automatically by the use of an internal lane standard. The y-axis displays fluorescent intensity in arbitrary units. 

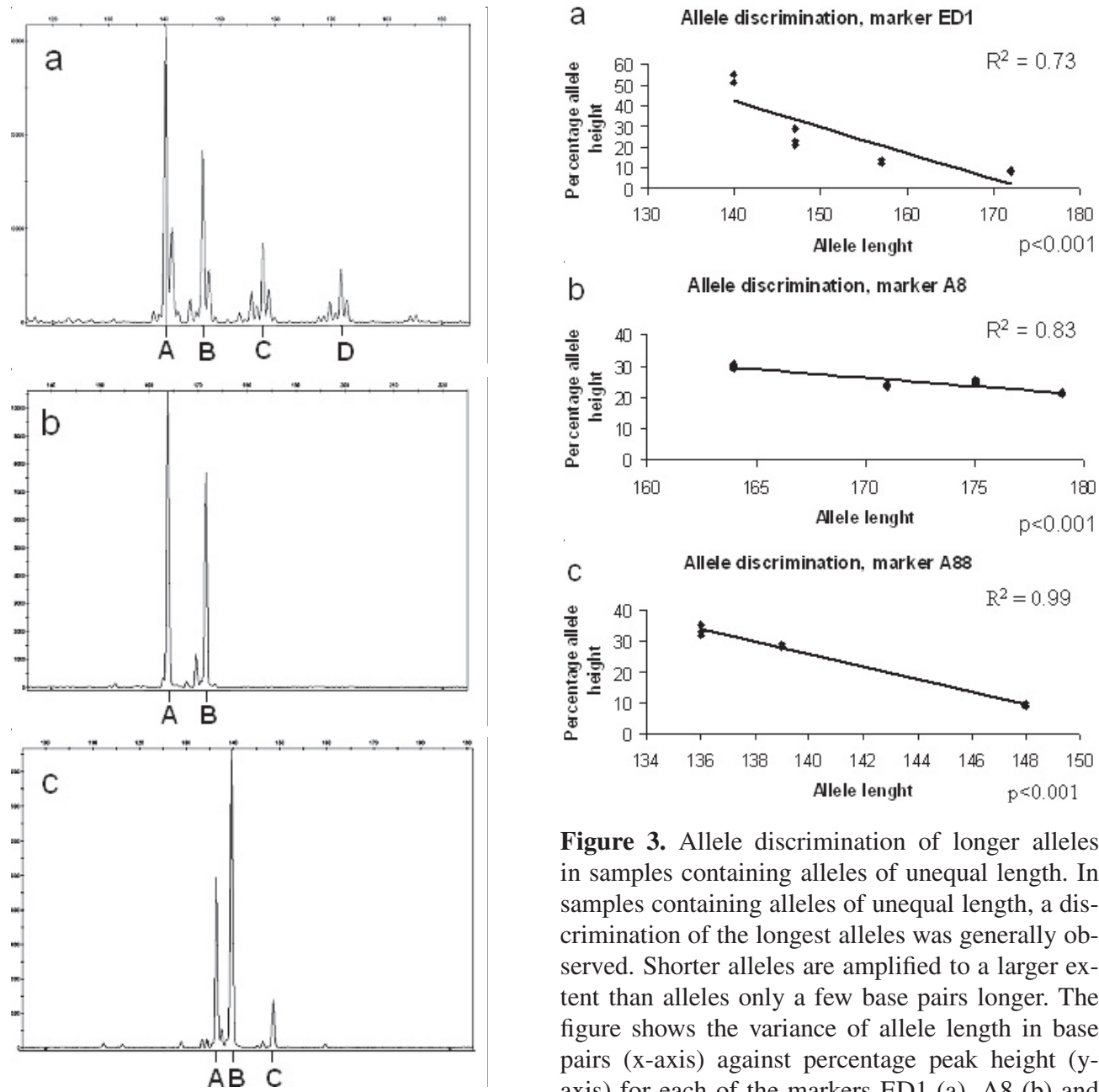

Figure 3. Allele discrimination of longer alleles in samples containing alleles of unequal length. In samples containing alleles of unequal length, a discrimination of the longest alleles was generally observed. Shorter alleles are amplified to a larger extent than alleles only a few base pairs longer. The figure shows the variance of allele length in base pairs ( $\mathrm{x}$-axis) against percentage peak height (yaxis) for each of the markers ED1 (a), A8 (b) and A88 (c). * In (b), samples with four alleles were used to get additional data for marker A8.

and longer alleles during PCR. In the PCR reactions, shorter alleles are regularly amplified to a larger degree than the longer alleles. The $\mathrm{x}$-axis displays the computed length of PCR products in base pairs, as determined automatically by the use of an internal lane standard. The y-axis displays fluorescent intensity in arbitrary units. (a) Ratio 50:50 of donor (alleles A and D) and recipient (alleles B and C) for marker ED1 in standard curve set-up number 1, (b) Ratio 50:50 of donor (allele A) and recipient (allele B) for marker A8 in standard curve set-up number 2, (c) Ratio 50:50 of donor (alleles $\mathrm{A}$ and $\mathrm{B}$ ) and recipient (alleles $\mathrm{B}$ and $\mathrm{C}$ ) for marker A88 in standard curve set up number 3 (allele 139 is shared and present in twice the amount of alleles 136 and 148 in the original sample, as can be seen in the amount of amplified PCR product).

et al., 2000), Real-Time PCR (Buno et al., 2001; Fehse et al., 2001) and Competitive PCR (Zhao et al., 1999) have been applied.

Our results demonstrate that the resolution level of the QF-PCR method is useful for studying detection of chimeras. With a resolution down to $1 \%$ the method was sensitive enough to detect the presence of very small amounts of donor material. Thus, if $20 \mu \mathrm{g}$ of DNA is extracted from a given larva, of which $100 \mathrm{ng}$ are used in PCR, donor DNA is detected if it constitutes $0.2 \mu \mathrm{g}(1 \%)$ or more of the total larvae DNA. This sensitivity enabled 

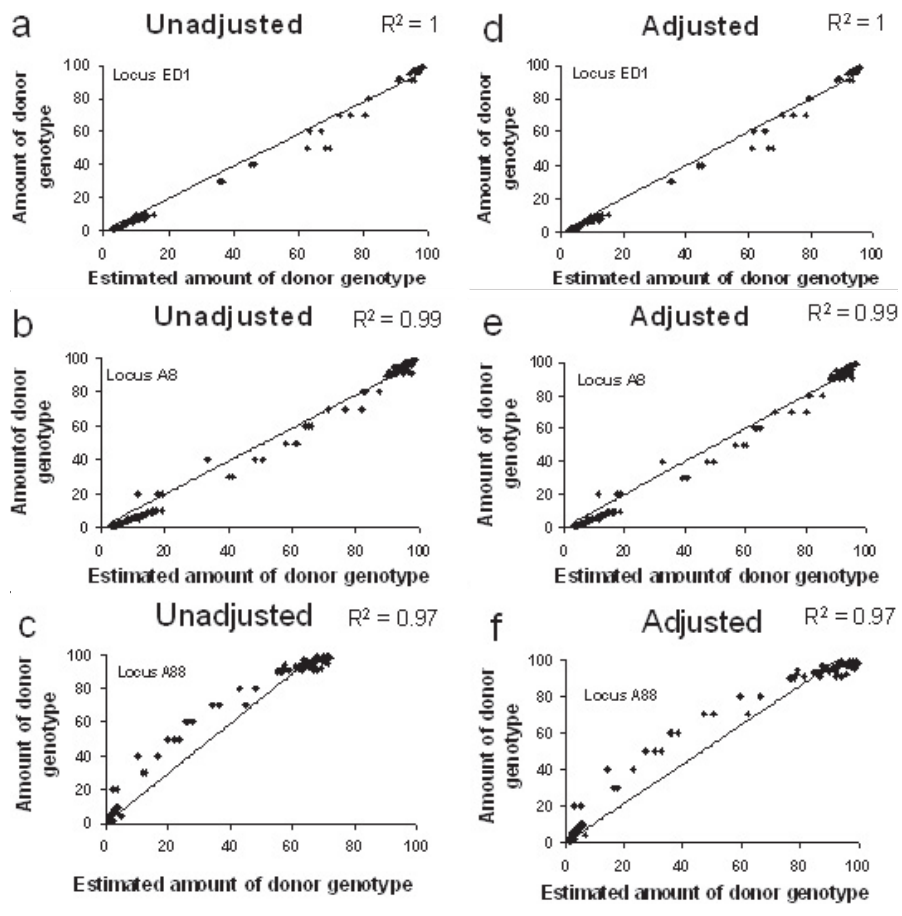

Figure 4. The three standard curves produced were adjusted by a correction factor to compensate for possible bias due to the long allele discrimination caused by the polymerase in PCR. Values from unadjusted curves $(\mathrm{a}-\mathrm{c})$ were multiplied with individually calculated factors for each marker and produced the adjusted standard curves $(\mathrm{d}-\mathrm{f})$, which demonstrated an approximately linear correlation between actual ratios of added donor genotype and ratios estimated by QF-PCR. The $\mathrm{x}$-axis displays estimated percentage amount of donor genotype as determined by QF-PCR. The y-axis displays actual percentage amount of donor genotype.

the detection of low-level chimerism, which with other less sensitive methods would go undetected. On the other hand the amount necessary for detection was high enough to reflect only the presence of active cellular material. With an ultra-high sensitivity one would risk false positives due to amplification of donor DNA not actually contributing to the cellular composition of the individual.

QF-PCR is an efficient and rapid method due to automatization by use of PCR, microcapillary electrophoresis and GeneMapper quantification. 96 samples were assayed within 5 hours, 192 samples within 7 hours. The method allowed multiplexing during PCR and the capillary electrophoresis, which enabled investigation of several loci simultaneously. Additionally, the demands for PCR reactants were low, as only one microliter of PCR product was required for the electrophoresis. Thus, the costs of the protocol were moderate.

A few potential sources of error emerged developing this method. Stutter bands are additional peaks, 2-6 base pairs shorter than the target allele and result from "slippery" amplification by the Taq polymerase during PCR (Nollet et al., 2001; Schraml and Lion, 2003). In the case of dinucleotide repeat loci, the most prevalent stutter band is generally two bases shorter than the main allele band. Probably this short stutter band simply lacks one core repeat unit relative to the main band (Walsh et al., 1996). The amount of stutter bands produced is proportional to the amount of original allele and range between $0.5-13 \%$ (Nollet et al., 2001). However, the stutter band interference is highly variable among different markers and 
should be used as an important criterion to exclude a marker for this kind of assay. In their report, Mansfield (1993) recommend the use of tri- or tetra-nucleotide repeats, when these are available, as these microsatellites produce less stutterbands.

A second type of unspecific peaks observed for some markers, were so-called double peaks. These result from the templateindependent terminal transferase activity of the Taq polymerase (Schraml and Lion, 2003). This activity leads to the preferential addition of adenosine residues at the 3'-end of the amplified fragment. However, the interference of double peaks was decreased by adding a final extension step of $25 \mathrm{~min}$ at $73^{\circ} \mathrm{C}$ towards the end of each PCR.

The standard curves showed that there is a close to linear relationship between the actual amount and the QF-PCR-estimated amount of donor and recipient genotypes. However, it is essential to include compensations for the preferential amplification of short alleles. In agreement with other groups (Mann et al., 2001; Lion, 2003), we observed a preferential amplification of short alleles in PCR. In such cases peak height and peak area produce signals based on different lengths of the alleles rather than the percentage distribution. To our knowledge there are no definitive explanations for this occurrence, but it has been suggested that the polymerase disconnects in long di- or trinucleotide repeats, as such sequences are capable of forming unusual DNA structures with simple and complex loop-folding patterns ( $\mathrm{Li}$ et al., 2002; Kristensen, unpublished data).

To adjust for this possible artefact we calculated the linear regression of true contribution of donor on estimated contribution of donor, and adjusted the estimated donor contributions by multiplying with this regression factor.

The adjusted standard curves displayed a corrected correlation between actual amount and QF-PCR-estimated amount of donor genotype. The regression factor was variable, dependent on the marker used. Thus, we recommend estimation of regression factors for each marker and the subsequent adjustment of the measured donor contributions.

Our experimental design reflects a realistic donor-recipient situation with a varying number of alleles involved. Prior knowledge about the genotypes of the patrilines and the queens chosen as egg donators is essential. Due to the high number of patrilines in a freely mated queen, which could produce an over-complex allele situation, we recommend the use of single drone-inseminated queens, preferably where the queen and the drone possess the same alleles for the markers to be used. By doing so only one standard curve is demanded for each marker, and the regression factor can be calculated instantly.

The main purpose of this study was to develop protocols to quantify genotypes in honeybee chimeras, to determine the success of the transplanted nuclei and cells after nuclear transfer and cell transplantation. QF-PCR may, however, be performed in all species with microsatellite markers available, which currently includes numerous vertebrate and invertebrate species. The method offers applications in species where access to genes and sequences are limited. Advantageously, microsatellites can be obtained from any tissue and from low amounts of template.

We believe this method may become a handy tool within honeybee research areas such as chimerism and reproductive cloning.

\section{ACKNOWLEDGEMENTS}

This research was supported by the Research Council of Norway. We wish to thank Stig W. Omholt and Theo Meuwissen for valuable comments and contributions on the manuscript.

Résumé - La PCR fluorescente quantitative sur microsatellites : une méthode rapide et quantitative pour tester des échantillons d'ADN chimériques d'Abeille domestique (Apis mellifera). Le but principal de cette étude était de mettre au point une méthode de détection et de quantification des génotypes de chimères d'abeilles domestiques (Apis mellifera) produites par transfert nucléaire et transplantation cellulaire. Il a été montré que les chimères, qui sont des individus issus de plus de deux lignées parentales, jouaient un rôle décisif dans la compréhension des problèmes importants de la biologie du développement et l'abeille domestique devenant un organisme modèle de plus en plus important, des protocoles pour étudier des abeilles chimériques deviendront un outil utile.

La PCR fluorescente quantitative (QF-PCR) a été autrefois utilisée pour détecter des maladies chromosomiques et pour examiner des patients ayant 
subi une transplantation de moelle osseuse. Nous rendons compte ici de l'utilisation d'un protocole QF-PCR pour détecter et quantifier les génotypes dans des échantillons d'ADN d'abeilles chimériques en s'appuyant sur des marqueurs microsatellites, des amorces marquées par fluorescence, l'électrophorèse microcapillaire et la quantification automatique.

Pour décrire le principe de la méthode, nous avons produit trois courbes standard, une pour chacun des trois microsatellites. Des échantillons artificiels d'abeilles chimériques ont été créés en mélangeant de l'ADN d'individus génotypés. Ils ont été utilisés pour fournir les données de chaque courbe standard. Nous avons utilisé des individus avec des allèles variables pour les trois marqueurs et créé des situations analytiques réalistes, où deux à quatre allèles apparaissaient sur un même locus. Les rapports donneur/receveur ont varié de 100/0 à 0/100. Les courbes standard ajustées (Fig. 2) montrent qu'il existe une étroite relation linéaire entre la quantité de chimérisme réelle et la quantité estimée par la QF-PCR. Nous recommandons d'utiliser comme donneurs d'œufs des reines inséminées par un seul mâle, puisqu'un nombre élevé de lignées paternelles produit un grand nombre d'allèles impliqués dans l'analyse. Nous avons pu détecter les génotypes donneurs jusqu'au niveau de $1 \%$. La méthode est rapide et sensible et, bien qu'elle ait été mise au point pour l'Abeille domestique, la QFPCR peut en principe être adaptée à tout organisme intéressant.

\section{PCR-fluorescente quantitative / microsatellite /} transfert nucléaire / chimère / Apis mellifera

\footnotetext{
Zusammenfassung - Quantitative-Fluoreszenz PCR (QF-PCR) für Mikrosatelliten, eine schnelle und quantitative Methode zur Analyse chimärer DNA-Proben von Honigbienen Apis mellifera. Hauptziel dieser Arbeit war es, eine Methode zur Detektion und Quantifizierung der Genotypen chimärer Honigbienen (Apis mellifera) $\mathrm{zu}$ entwickeln. Chimären sind Individuen, die aus mehr als zwei Elterlinien, z.B. durch Kern- bzw. Zelltransplantation hervorgingen. Sie sind wichtig für das Verstehen von Entwicklungsvorgängen, und da die Honigbiene zunehmend zu einem Modellorganismus wird, gewinnen experimentelle Verfahren zur Erzeugung von Chimären zunehmend an Bedeutung.

Quantitative Fluoreszenz PCR (QF-PCR) wird bereits eingesetzt, um chromosomal bedingte Krankheiten $\mathrm{zu}$ erkennen und auch um Patienten nach Knochenmarktransplantationen $\mathrm{zu}$ untersuchen. Wir beschreiben hier ein QF-PCR Verfahren zur Detektion und Quantifizierung chimärer Honigbienenproben. Es basiert auf Mikrosatellitenmarkern, Fluoreszenz-markierten Primern, Mikrokapillarelektrophorese und automatisierter Quantifizie-
}

rung. Um das Prinzip der Methode aufzuzeigen, erzeugten wir Standardkurven für drei Mikrosatelliten. Künstliche Chimärenproben wurden durch die Mischung von DNA genotypierter Bienen hergestellt, und jede dieser Proben wurde mit den Standardkurven verglichen. Zur Simulierung realistischer Analysesituationen benutzten wir Bienen mit unterschiedlichen Allelen in den drei Markern, die jeweils zwei bis vier Allele pro Locus aufwiesen. Die DNA-Verhältnisse Spender/Empfänger variierten zwischen 100:0 und 0:100. Die korrigierten Standardkurven (Abb. 2) zeigten eine enge lineare Beziehung zwischen der mittels QF-PCR gemessenen und der geschätzten Menge chimärer DNA. Für derartige Analysen empfehlen wir die Verwendung von einzelbegatteten Königinnen als Eispenderinnen, da eine hohe Zahl an Patrilinien eine Vielzahl an Allelen erzeugen kann, die alle getrennt analysiert werden müssten. Wir konnten Spendergenotypen bis auf ein $1 \%$-Niveau detektieren. Die Methode erwies sich als schnell und sensitiv, und obwohl sie hier speziell für Honigbienen standardisiert wurde, kann die QF-PCR-Methode im Prinzip für jeden Organismus von Interesse etabliert werden.

Quantitative Fluoreszenz PCR (QF-PCR) / Mikrosatelliten / Kerntransfer / Honigbiene / Apis mellifera

\section{REFERENCES}

Adinolfi M.C., Sherlock J., Pertl B. (1995) Rapid detection of selected aneuploidies by quantitative fluorescent PCR, BioEssays 17, 661-664.

Adinolfi M., Pertl B., Sherlock J. (1997) Rapid detection of aneuploides by microsatellite and the quantitative fluorescent polymerase chain reaction, Prenat. Diagn. 17, 1299-1311.

Bergem M., Norberg K., Roseth A., Meuwissen T., Lien S., Aamodt R. (2006) Chimeric honeybees (Apis mellifera) produced by transplantation of embryonic cells into pre-gastrula stage embryos and detection of chimerism by use of microsatellite markers, Mol. Reprod. Dev. 73, 475-481.

Buno I., Maas F., Pennings A., Diez-Martin J.L., de Witte T., van de Wiel-van Kemenade E. (2001) Chimerism quantification in alpha-beta and gamma-delta $\mathrm{T}$ lymphocytes after BMT: a pilot study using real-time quantitative PCR of single nucleotide polymorphisms, Bone Marrow Transplant. 27, S228-S228.

Cawkwell L., Bell S.M., Lewis F.A., Dixon M.F., Taylor G.R., Quirke P. (1993) Rapid detection of allele loss in colorectal tumors using microsatellites and fluorescent DNA technology, $\mathrm{Br}$. J. Cancer 67, 1262-1267. 
Delhaise F., Zhao X., Bralion V., Dessey F. (1993) Quantitative estimation of chimerism in mice using microsatellite markers, Mol. Reprod. Dev. 34, 127-132.

Fehse B., Chukhlovin A., Kuhlcke K., Martinetz O., Vorwig O., Renges H., Kruger W., Zabelina T., Dudina O., Finckenstein F.G., Kroger N., Kabisch H., Hochhaus A., Zander A.R. (2001) Real-time quantitative y chromosome-specific PCR (QYCSPCR) for monitoring hematopoietic chimerism after sex-mismatched allogeneic stem cell transplantation, J. Hematother. Stem Cell Res. 10, 419-425.

Illmensee K. (1968) Transplantation of embryonic nuclei into unfertilised eggs of Drosophila melanogaster, Nature 219, 1268-1269.

Li Y.C., Korol A.B., Fahima T., Beiles A., Nevo E. (2002) Microsatellites: genomic distribution, putative functions and mutational mechanisms: a review, Mol. Ecol. 11, 2453-2465.

Lin S., Long W., Chen J., Hopkins N. (1992) Production of germ-line chimeras in zebrafish by cell transplantation from genetically pigmented to albino embryos, Proc. Natl. Acad. Sci. USA 89, 4519-4523.

Lion T. (2003) Summary: Reports on quantitative analysis of chimerism after allogenic stem cell transplantation by PCR amplification of microsatellite markers and capillary electrophoresis with fluorescence detection, Leukemia 17, 252-254.

Mann K. Fox S.P., Abbs S.J., Yau S.C., Scriven P.N., Docherty Z., Ogilvie C.M. (2001) Development and implementation of a new rapid aneuploidy diagnostic service within the UK National Health Service and implications for the future of prenatal diagnosis, Lancet 358, 1057-1061.

Mansfield E.S. (1993) Diagnosis of Downs syndrom and other aneuploidies using quantitative polymerase chain reaction and small tandem repeat polymorphisms, Hum. Mol. Genet. 2, 43-50.

Martens U.M., Brass V., Finke J., Lange W. (2000) Quantitative analysis of mixed chimerism following angiogenic bone marrow transplantation using teleomere Flow-FISH, Blood 96, 3311.

Moritz R.F.A., Scharpenberg H., Lattorff H.M.G., Neuman P. (2003) A technical note for using microsatellite DNA analyses in haploid male DNA pools of social Hymenoptera, Insectes Soc. 50, 398-400.
Nollet F., Billiet J., Selleslag D., Criel A. (2001) Chimerism. Standardisation of multiplex fluorescent short tandem repeat analysis for chimerism testing, Bone Marrow Transplant. 28, 511-518.

Oberkircher A.R.R., Strou M.P., Herzig G.P., Fritz P.D., Caligiuri M.A. (1995) Description of an efficient and highly informative method for the hematopoietic chimerism following allogeneic bone marrow transplantation, Bone Marrow Transplant. 16, 695-702.

Omholt S.W., Rishovd S., Hagen A., Elmholdt O., Dahlsgård B., Fromm S. (1995) Successful production of chimeric honeybee larvae, J. Exp. Zool. 272, 410-412.

Rowe D.J., Rinderer T.E., Stelzer J.A., Oldroyd B.P., Crozier R.H. (1997) Seven polymorphic microsatellite loci in honeybees (Apis mellifera), Insectes Soc. 44, 85-93.

Schraml E., Lion T. (2003) Interference of dyeassociated fluorescence signals with quantitative analysis of chimerism by capillary electrophoresis, Leukemia 17, 221-223.

Solignac M., Vautrin D., Loiseau A., Mougel F., Baudry E., Estoup A., Garnery L., Haberl M., Cornuet J.M. (2003) Five hundred and fifty microsatellite markers for the study of the honeybee (Apis mellifera L.) genome, Mol. Ecol. Notes 3, 307-311.

Tarowski A.K. (1961) Mouse chimeras developed from fused eggs, Nature 190, 857-860.

Walsh S.P., Fildes N.J., Reynolds R. (1996) Sequence analysis and characterization of stutter products at the tetranucleotide repeat locus vWA, Nucleic Acids Res. 24, 2807-2812.

West J.D. (1999) Insight into development and genetics from mouse chimeras, in: Pedersen R.A., Schatten G.P. (Eds.), Current topics in Developmental Biology, Academic Press, USA, pp. 21-66.

Zhao Y., Lan F., Gan J., Yao X., Reisner Y. (1999) Donor-type chimerism determination by competitive polymerase chain reaction (PCR) in a primate model for bone marrow transplantation, Transplantation 68, 1573-1577. 